\title{
Zuzanna Samson
}

Leiden University (Netherlands)

\section{Poland's Energy Security Strategy}

\begin{abstract}
Poland, as one of the European countries experiencing the most significant economic growth in recent years, permanently relies on coal power. There are plenty of reasons behind this condition, however, wanting to become one of the European leaders Poland ought to diversify its energy sources and lower the share of those harmful to the natural environment. Some changes have already been implemented, nevertheless the Polish government is mostly reluctant to diminish the role of coal mines. Moreover, the current actions taken to diversify sources of natural gas imports are dependent on Polish foreign policy and international alliances. The author analyzes changes in the Polish energy security strategy in recent years and compares them with provisions established during COP24. The article analyzes the Polish energy market with the share of individual sources and examines the possibility to increase the share of those alternative to coal in the near future.
\end{abstract}

Keywords: Poland, national energy security, coal, renewable energy sources, natural gas, LNG, COP24

\section{Introduction}

On March $29^{\text {th }}, 2018$ the president of Poland, Andrzej Duda, signed a bill ratifying the Doha Amendment to the Kyoto Protocol. Thus Poland has become the last European Union member-state required to enact it by the EU as a whole (Barteczko, 2018). The Kyoto Protocol, concluded in 1997, obliged its signatories to reduce greenhouse gas emission by at least $5 \%$ up to 2008-2012, comparing to the 1990 emission levels. Poland has reduced its emissions by almost $15 \%$ up to 2012, being one of the countries with the most substantial reduction level in Europe. What is more, as a former socialist country, the Polish government had to change the structure of the economy, eventually noting reduction of $\mathrm{CO}_{2}$ emission by $33 \%$ in years 1988-2001, subsequently earning on its surplus trading (King, 2015).

In 2012, in the capital of Qatar - Doha, countries agreed that the Kyoto Protocol is going to apply until the end of 2020, calling it the second commitment period, and that a new climate agreement was to be concluded in 2015. In fact, it was only the EU that had 
fulfilled the Doha Amendment provisions, committing to reduce its $\mathrm{CO}_{2}$ emission by $20 \%$ until 2020 (Centrum Informacji o Rynku Energii, 2018). In December 2015 the first global climate agreement was negotiated at the Paris Climate Summit, according to which all states were obliged to take action to protect the climate. The main goal of the Paris Agreement is to maintain the global average temperature increase at a level significantly lower than $20 \mathrm{C}$ compared to the pre-industrial age. This new global climate agreement has been effective since November 2016 and in December 2018 specific directions of its implementation were set at the climate summit COP24 in Katowice, Poland (Skłodowska, 2018).

Poland is evaluated exceptionally well compared to other countries, as the $\mathrm{CO}_{2}$ emission was reduced by $30 \%$ in comparison to the 1988 levels, while the Kyoto Protocol required from Poland only $6 \%$. But how can the greenhouse gas emission be reduced even more? There are two principal solutions. First, Poland can invest in increasing greenhouse gas absorption, for example by intensive afforestation; and second, it can switch the sources of energy from the heavy industry, like coal power, to more eco-friendly and renewable energy sources, for example wind, solar and water energy or the nuclear power (Polish Ministry of the Environment, 2003). Even natural gas is a better option than coal, and coal is still Poland's biggest problem.

The purpose of this article is to present the key aspects of energy security policy in Poland, in the perspective of provisions established during COP24 - Conference of the Parties to the United Nations Framework Convention on Climate Change held in Katowice in December 2018. The author presents features of the current energy policy of Poland and compare plans and possibilities for the future considered by the Polish government, with the international agenda for sustainable energy usage discussed at COP24. The author answers the following research question: how does the current energy security strategy of Poland fulfil international standards for sustainable energy usage, complying with the climate ambitions? In the article, the author argues that the Polish energy strategy is principally based on the obsolete and harmful to the environment sector of coal mining, and the proposed alternations are mostly driven by economic or political calculations, and not by the concern for climate change.

Methodology applied for the article is comparative data analysis. The statistical data used in the analyses come from research provided by Eurostat, as well as from reports and publications prepared by both governmental and independent organizations, analyzing the Polish energy market.

The article is organized as follows: First, I present the concept of national energy security and how significant it is, according to the state security system, and I apply it to the example of Poland. The second section is devoted to the analysis of current energy market in Poland, exploring the principal sources of energy and the possibilities for future alterations. Lastly, section three explores how the Polish energy security strategy fulfils international standards for sustainable energy usage, complying with climate change concerns. 


\section{The Concept of National Energy Security}

According to Pach-Gurgul (2013, p. 86), energy security is a dynamic process, which is changing over time. It used to be perceived as a secondary issue within a states' domestic politics, not vital for functioning of the economy. Until the Second World War it remained out of the domain of state strategic planning (Kaczmarski, 2010, p. 11). The oil crisis of 1973 changed the perception of energy resources, which became considered as important factors affecting world politics. The first decade of the $21^{\text {st }}$ century emphasized the role of energy resources even more, with such events as war in Iraq or the Russian-Ukrainian gas crisis. Today, with the concerning issues like global warming or decreasing amount of oil supplies, energy security became considered as having strategic significance in the functioning of states' economies (Pach-Gurgul, 2010, p. 87).

Umbach (2008, pp. 1-23) defines energy security as "the availability energy which is adequate, at a reasonable price, reliable, indispensable, both from the point of view of technological development and from the perspective of human security", however the International Energy Agency (IEA) emphasizes the desired problem-management characteristics of energy security (IEA, 2007, p. 161). Pach-Gurgul (2010,p. 88) argues that the state of energy security can be described as "continuous access to energy at a reasonable price", simultaneously taking into consideration the issues of environmental protection. Nevertheless, energy security is closely related to geographic location, geologic resources or relationships with neighbors of a given country, and its political and economic system, thus it can mean different things for each country (Luft, Korin, 2009, pp. 5-6).

The Polish energy security strategy is mostly dependent on two factors: the European Union's energy agenda and the importance of Russian gas on the continent. According to the politics of the currently ruling government of Law and Justice (PiS), energy security is a term defined as part of national security, emphasizing the importance of possessing "uninterrupted access to raw materials and energy at reasonable price", which in turn impacts the manners of production and consumption, and in effect the whole economy (Pach-Gurgul, 2010, p. 87).

\section{The Energy Market in Poland}

Currently over $80 \%$ of energy produced in Poland comes from coal and the government of Law and Justice is supporting the maintenance of, often unprofitable, coal mines due to the large amount of employees in this sector (about half a million people) (Business Insider Poland, 2018). Clearly, not all $\mathrm{CO}_{2}$ emission is caused by coal, but according to The European Union Emission Trading System data, in 2017 38\% of the EU's emissions came from coal power plants (Buckley, 2017). And even though six out of the ten "dirtiest" powerhouses in the EU are located in Germany, Poland is on the fifth place having the Bełchatów power station, producing 37.6 million tons of $\mathrm{CO}_{2}$, and the Polska Grupa Energetyczna (Polish Energetic 
Group) as a whole, which is producing 58 million tons of $\mathrm{CO}_{2}$ annually (Drabińska, 2014). It is often said that classical mining should be liquidated, however, at a pace appropriate for the Polish economy. And what is more important, changes need to be implemented within the Polish society and in Polish houses, as around 3.5 million single-family houses (70\%) require replacement of boilers or thermomodernization (Dudała, 2018).

Table 1. The largest CO2 emitters in Europe (2016)

\begin{tabular}{lc}
\hline CO2 emitter & Amount of CO2 emitted annually \\
\hline RWE (Germany) & 144 million tons \\
\hline Vattenfall (Sweden) & 90 million tons \\
\hline Enel (Italy) & 71 million tons \\
\hline E.ON (Germany) & 60 million tons \\
\hline PGE (Poland) & 58 million tons \\
\hline
\end{tabular}

Source: WysokieNapiecie.pl, 2016.

Furthermore, Poland is not investing enough to develop renewable energy sources, and the Polish society is mostly reluctant to atomic energy on account of fear of nuclear accidents similar to the one in Chernobyl. The participation of renewable energy in Poland is about 4.4 $\mathrm{GW}$, including: biomass $-22 \%$, biogas $-4 \%$, solar installations $-0.3 \%$, hydropower $-16 \%$ and wind farms $-58 \%$. The most potential in producing energy on a larger scale in Poland is solar energy, as it is the most available installation for a single household. Yet, in Poland it produces only around $800 \mathrm{MW}$ while in Germany with a similar surface - 33 thousand MW. The dynamic development of investing in wind farms has been noticed since the first years of $21^{\text {st }}$ century. The potential of such power plants has been systematically growing, currently producing almost 155 thousand MW of energy in Poland, where 1193 wind installations were operated in 2017 (Wiśniewski, 2017).

Table 2. The share of renewable energy sources on the Polish energy market (2017)

\begin{tabular}{|l|c|c|}
\hline Renewable energy source & Share in Megawatts (MW) & Share in percentage \\
\hline Wind farms & 154667 & $58 \%$ \\
\hline Biomass & 58667 & $22 \%$ \\
\hline Hydropower & 42667 & $16 \%$ \\
\hline Biogas & 10667 & $4 \%$ \\
\hline Solar installations & 800 & $0.3 \%$ \\
\hline
\end{tabular}

Source: own elaboration based on Wiśniewski, 2017.

On March $6^{\text {th }} 2018$ the Polish government adopted a draft amendment to three acts: on renewable energy sources from 2015, on investments in wind farms and wind farm construction law. The changes are to provide support for small energy generators and set lower prices for purchasing energy from renewable sources. The amendments came into 
force in July 2018 (Stowarzyszenie Energii Odnawialnej, 2018). It is a response to the EU Directive of 2009, according to which the EU member states are obliged to ensure a specific share of energy from renewable sources in the final energy consumption by 2020 . For Poland the target is $15 \%$ and currently it produces slightly over $11 \%$ of energy from renewable sources and, what is worse, this percentage is gradually falling, which may effect in financial penalties from the EU (Zaleski, 2015).

The construction of the first nuclear plant in Poland is being planned for over 35 years while the world has already started to move away from this source of energy. However, despite some controversy and high costs this topic constantly reappears among Polish policymakers. Since the catastrophe in Chernobyl in 1986 plans to build a nuclear plant in Poland have been abandoned, then in 2009 the Polska Grupa Energetyczna brought back these projects and again they were being continuously postponed, partly because of the Fukushima accident in 2011, and after a few years the government announced that Poland will start investing in nuclear power in 2030. In practice, no work related to the construction of the power plant has begun but the government spent millions of zlotys for salaries, analyses and other research of which absolutely nothing resulted (Kosiński, 2017). After all, the only functioning nuclear reactor in Poland is the research reactor "Maria" in Świerk.

Nonetheless, nearly 10 nuclear power plants operate in the vicinity of Poland's borders: in Germany, Russia, Ukraine, Lithuania, Slovakia and the Czech Republic. Recently, the decision to build a nuclear power plant was taken by Belarus (Prus, 2017). Thus, regardless of the Polish point of view, Poles are at risk of catastrophe. In other words, building or not the nuclear power plant in Poland will not have an impact on peoples' safety while the benefits for Poland's energy security can increase significantly. However, it is necessary for the government to undertake a wide-scale information campaign. Gathered from different polls, the average Pole among the most common reasons for his/her opposition to the nuclear power plants in Poland, gives concern to the consequences of power plant failure (54\% of the respondents), associates nuclear power with the Chernobyl accident (51\%) and does not possess enough information on the risks and benefits of nuclear energy (26\%) (Gwiazda, Ruszkowski, 2016).

\section{LNG as the Future Replacement of Coal?}

Since 2017 the importance of natural gas in Poland has been growing. In 2015 it was in 90\% imported from Gazprom but due to Poland's complex and difficult relations with Russia, the search for alternative sources of gas is accelerating. At present, Gazprom provides only $59 \%$ of the country's annual gas consumption and many undertaken projects, among them the Three Seas Initiative, strive for replacing Russian gas with the liquified gas from Norway and the United States. Not only Central and Eastern European countries will become independent from gas supplies from Russia, but also LNG purchase will become much cheaper for them (Furfari, 2017). The European Commission foretells that gas consumption will increase by 
2030 in the Three Seas Initiative countries by approximately $14 \%$ compared to 2015 , while in the EU as a whole it is expected to drop by approximately $4 \%$. The largest increase will be noticed in Poland, Slovenia, Latvia and Austria (Eurostat, 2017).

As a replacement for Russian gas there has been established a plan to build a so-called North-South Gas Corridor, consisting of two main parts:

1. The Northern Gate connecting Denmark and Poland with Norwegian natural gas deposits on the North Sea shelf via the Baltic Pipe;

2. the North-South Gas Corridor linking LNG Terminal in Świnoujście with adjacent systems further through the Czech Republic, Slovakia and Hungary to the LNG Terminal in Croatia on the island of Krk.

The project also involves selling gas to Ukraine. This strategy of the Three Seas Initiative proposes to import 10 billion cubic meters of gas by 2022 when the current contract with Russia's Gazprom expires, but in 2017 Poland consumed about $15 \mathrm{bcm}$, so the initiative will not entirely fulfil Polish gas demands. The installations are planned to be constructed by 2022 and it will cost between 1.6-2.2 million euro. The main investors are mentioned as: Gas-System, a Polish joint-stock company, Gassco (Norway) and Energinet.dk (Denmark) (Ośrodek Studiów Przestrzeni Postsowieckiej, 2017).

Moreover, in November 2017 Poland signed a 5-year contract with Centrica Company for importing LNG supplies from the USA. The gas will come from the Sabine Pass Terminal in Louisiana and will be received at the Terminal in Swinoujście. The final contract is going to be signed at the end of 2019 (Polskie Radio, 2018). The Polish Minister of Energy, Krzysztof Tchórzewski, claimed that the deliveries will reach a total of 1 billion cubic meters, which is not much as for the Polish annual consumption. The contract therefore does not significantly increase Poland's energy security. However, it will be based on the Delivery Ex Ship Rule, which states that the price formula of the contract indicates the final value of the deliveries and that the responsibility for transport is borne by the supplier. This in turn means that the price of LNG supplies from the USA is much lower and permanently competitive to the other offers, including Russian ones (Jakóbik, 2017). In 2022, when contracts with Gazprom and Centrica expire, new Polish LNG contracts may not include delivery from Russia. According to the forecast of the International Energy Agency and the Fitch agency at the turn of the decade, liquefied gas from the USA will become the main competitor of supplies from Russia in Europe (International Energy Agency, 2018). Polskie Górnictwo Naftowe i Gazowe (The Polish Oli and Gas Mining) may contribute to a drop in prices on the Polish market and hit the status quo that Gazprom has defended for so many years.

The other alternative is LPG - Liquified Petroleum Gas. Investing in LPG is much cheaper, as producing $1 \mathrm{MW}$ of energy costs 3 million zlotys, while the same amount of energy produced by coal power plant costs even twice as much. Liquified gas is called "the fuel of the future", more efficient than natural gas which requires conventional infrastructure. Investing in liquified gas could solve the social problem of energy poverty, particularly prominent in 
rural, non-urbanized areas (93\% of Polish territory, $40 \%$ of Polish population) (PBL 2016), but today it participates in Polish energy market in only 3\% (Śmigiel, 2017).

Table 3. Energy sources in Poland (2018)

\begin{tabular}{lc}
\hline Energy source & Share in percentage \\
\hline Coal & $80 \%$ \\
\hline Renewable energy sources & $11 \%$ \\
\hline Natural gas & $6 \%$ \\
\hline LNG & $3 \%$ \\
\hline
\end{tabular}

Source: own elaboration based on WysokieNapiecie.pl, 2018.

\section{Poland's Energy Security Strategy in the Perspective of COP24 Agreements}

The global conference COP24 was concluded with signing the so-called Katowice Rulebook, which constitutes the implementation plan for the Paris Agreement. The conference introduced a new international climate regime, according to which all countries are obliged to report their $\mathrm{CO}_{2}$ emissions and progress in cutting them every two years from 2024 . The Rulebook included the guidance for countries on how to measure, report and verify their emission-cutting efforts. The participants also discussed the role of carbon credits, awarded to the countries for effective carbon-cutting efforts, as well as carbon sinks, like for example forests (Harvey, 2018).

The choice to hold the $24^{\text {th }} \mathrm{COP}$ in Katowice was very significant, as the city is called "the heart of Poland's coal country", due to the dominant numbers of coal mines located in the Silesian region. According to Evans and Timperley (2018), the delegates to the conference were "met by the taste of coal in the air and high levels of smog". Nevertheless, the host of the conference tried to present coal from the positive perspective inside the Katowice pavilion, featuring walls, floors, soap and jewelry made from coal. Moreover, president Andrzej Duda gave his opening speech about the advantages of using coal power, ending with the sentence that "there is no plan today to fully give up on coal" (Evans, Timperley, 2018).

Nevertheless, the Polish presidency launched several propositions during the conference, such as "Silesia declaration" signed by 50 countries, which highlighted the emission-reducing policies considering a just transition of the workforce, especially important from the Polish perspective with large numbers of coal miners. Another declaration proposed by Poland was "Declaration on Forests for the Climate", emphasizing the important role of forests in reaching the Paris Agreement goals. However, intensive afforestation is rather a domestic initiative and it would only partly contribute to solving the problem, as it may delay efforts to actually reduce $\mathrm{CO}_{2}$ emissions (Evans, Timperley, 2018).

The Conference of the Parties to the United Nations Framework Convention on Climate Change was held in the atmosphere of hope for the future, during which parties intended 
to improve the current situation on the energy market and infrastructure, contributing to the changes in natural environment. Nevertheless, Poland as a host of the conference firmly presented its pride in the large national coal resources, thus manifesting its energetic independence, however it simultaneously revealed the short-sighted and old-fashioned approach to energy strategy of the Polish officials. It also exhibited the divergent view on the energy markets and the lack of concern for the natural environment in the global scale.

\section{Conclusions}

The article has analyzed the current energy market in Poland and its strategy for ensuring security in this sector according to the international politics. To summarize, rather than banishing coal from day to day, Poland should try to complement it. No state can rely on one source of energy, whether it is coal, an atom, solar panels or liquified gas. There is a necessity to diversify and invest in all possible solutions, yet still considering environmental protection. Only then will it be possible to ensure Poland's energy security in a long term view.

Polish electric energy is in approximately $80 \%$ relying on coal. The share of renewable sources is secondary with $11 \%$, however the difference is enormous, and the predictions for its reduction are not promising, as the share of using renewable energy sources is falling despite the European Union's target of 15\% until 2020. The infrastructure for using natural gas and LNG are still developing, however they are both loaded with political controversies concerning either relations with Russia or with the United States. Moreover, the substantially modest amounts of LNG planned to import from the USA will not be sufficient to supplement coal, but are rather intended to back out Russian natural gas (Mikulska, Kosiński, 2018).

The problem with Polish coal is connected to the term of national energy security. Because Poland lacks significant amount of other natural resources, coal constitutes an important part of Polish national energetic security and independence. Thus, it has a positive impact on energy security. However, it is a source relying on outdated technologies and dangerous work often threatening miners' lives. Mostly unprofitable mines are straining the national budged, as the government has to financially contribute to maintaining the mines and providing miners workplaces. Finally, coal powerhouses are the immense producers of $\mathrm{CO}_{2}$. Thus, Poland's energy security is relatively low according to its environmental dimension. Pach-Gurgul (2010, p. 104) argues that this is the main reason for the Polish government to consider implementation of modern technologies entirely independent from coal, or the so-called "clean coal technologies", which could enhance Polish energy security. However, the Polish energy policy goals to 2030, introduced in 2009, included such provisions as improvements in energy efficiency and security, a wider use of renewable sources or limitation of the negative impacts of energy usage on the environment (Nyga-Łukaszewska, 2011).

Lastly, the Polish government should consider improving the share of renewable energy sources, especially according to its aspirations in becoming one of the European leaders according to sustainable development. Its promising economy, improving from year to year, 
could greatly benefit from sustainable energy usage, concerned about the environment in the global perspective.

\section{References}

Barteczko, A. (2018, March 29). Poland's president signs bill on global climate deal amendment. Reuters. Retrieved from: https://www.reuters.com/article/us-climatechange-accord-eu/polands-presidentsigns-bill-on-global-climate-deal-amendment-idUSKBN1H52CX. Buckley, P. (2017, November 30). State of the EU Emission Trading System 2017. Sandbag. Retrieved from: https://sandbag.org.uk/ wp-content/uploads/2017/11/State-of-EU-ETS-2017-by-Sandbag-1.pdf.

Business Insider Poland. (2018, March 5). Polska w 2017 więcej wegla kupita, niż sama sprzedała. Jesteśmy jednak na plusie, Retrieved from: https://businessinsider.com.pl/finanse/handel/wynikipolskiego-gornictwa-w-2017-r/gwdpv55.

Centrum Informacji o Rynku Energii. (2018, April 18). Nowe cele redukcji CO2 w non-ETS. Jaki cel dla Polski?. Retrieved from: https://www.cire.pl/item,161621,1,0,0,0,0,0,nowe-cele-redukcji-emisji-co2w-non-ets-jaki-cel-dla-polski.html.

Drabińska, U. (2014, July 24). Polska wśród największych trucicieli Europy. Chrońmy Klimat. Retrieved from: http://www.chronmyklimat.pl/wideo/energetyka/polska-wsrod-najwiekszych-trucicieli-europy.

Dudała, J. (2018, April 19). Rosna obawy sprzedawców polskiego wegla. Ale chca walczyć. Portal gospodarczy wnp.pl. Retrieved from: http://gornictwo.wnp.pl/rosna-obawy-sprzedawcow-polskiegowegla-ale-chca-walczyc,321789_1_0_0.html.

Dudała, J. (2017, November 24). Jaka przyszłość górnictwa w Polsce?. Portal gospodarczy wnp.pl. Retrieved from: http://gornictwo.wnp.pl/jaka-przyszlosc-gornictwa-w-polsce,311503_1_0_0.html.

Eurostat. (2017). Natural gas consumption statistics. http://ec.europa.eu/eurostat/statistics- explained/ index.php/Natural_gas_consumption_statistics.

Evans, S., Timperley J. (2018, December 16). COP24: Key outcomes agreed at the UN climate talks in Katowice. Carbon Brief. Retrieved from: https://www.carbonbrief.org/cop24-key-outcomes-agreedat-the-un-climate-talks-in-katowice.

Frączyk, J. (2018, February 4). Polacy zignorowali energetykę odnawialną. Groża nam wielkie kary $z \quad$ Unii. Money.pl. Retrieved from: https://www.money.pl/gospodarka/wiadomosci/artykul/ozeenergetyka-odnawialna-kary-ue,134,0,2397318.html.

Furfari, S. (2017, June 13). Seeking energy security, Poland welcomes US natural gas but defends coal power. The Conversation. Retrieved from: https://theconversation.com/seeking-energy-securitypoland- welcomes-us-natural-gas-but-defends-coal-power-78704.

Gwiazda, M., Ruszkowski, P. (2016). Polacy o źródłach energii, polityce energetycznej i stanie środowiska. Opinie i Diagnozy, No. 34, CBOS. Harper, J. (2017, November 17). US-Poland energy deal bucks anti-coal trend. Deutsche Welle. Retrieved from: https://www.dw.com/en/us-poland-energy-dealbucks-anti-coal-trend/a-41419864.

Harvey, F. (2018, December 16). What was agreed at COP24 in Poland and why did it take so long? The Guardian. Retrieved from: https://www.theguardian.com/environment/2018/dec/16/what-wasagreed-at-cop24-in-poland-and-why-did-it-take-so-long.

International Energy Agency. (2007). World Energy Outlook 2007. Retrieved from: http://www.env-edu. gr/Documents/International\%20Energy\%200utlook\%202007.pdf. 
International Energy Agency. (2018). Gas 2018. Retrieved from: https://www.iea.org/gas2018/. Jakóbik, W. (2017, November 21). Tajemnicza formuła kontraktu na LNG $z$ USA dla PGNiG. Biznes Alert. Retrieved from: http://www.energetyka-polska.pl/default_037.html.

Kaczmarski, M. (2010). Bezpieczeństwo energetyczne Unii Europejskiej. Warsaw: Wydawnictwa Akademickie i Profesjonalne.

King, E. (2015, October 27). Polish president vetoes Kyoto Protocol, pending new analysis. Climate Change News. Retrieved from: http://www.climatechangenews.com/2015/10/27/polish-presidentvetoes-kyoto-protocol-pending-new-analysis/.

Kosiński, D. (2017, August 3). Lepiej późno niż wcale. W Polsce w końcu powstanie elektrownia atomowa.Spider's Web. Retrieved from: https://www.spidersweb.pl/2017/08/elektrownia-atomowaw-polsce.html.

Luft, G., Korin, A. (2009). Energy Security Challenges for the 21 $1^{\text {st }}$ century: A Reference Handbook. California: ABC CLIO Santa Barbara.

Mikulska, A., Kosiński, E. (2018, March 28). Explaining Poland's Coal Paradox. Forbes. Retrieved from: https://www.forbes.com/sites/thebakersinstitute/2018/03/28/explaining-polands-coalparadox/\#6a5f472a4867.

Nyga-Łukaszewska, H. (2011, March 15). Poland's Energy Security Strategy. Journal of Energy Security. Retrieved from: http://www.ensec.org/index.php?option=com_content\&view=article\&id=279:asses sing-polands-energy-security-strategy\&catid=114: content0211\&Itemid=374.

Pach-Gurgul A. (2010). Poland's Energy Security in Light of a Statistical Analysis. Comparative Economic Research, No. 13, pp. 85-106.

PBL Netherlands Environmental Assessment Agency, Nabielek, K., Hamers, D., Evers, D. (2016). Cities in Europe. The Hague. Retrieved from: http://www.pbl.nl/sites/default/files/cms/publicaties/PBL2016-Cities-in-Europe-2469.pdf.

Ośrodek Studiów Przestrzeni Postsowieckiej. (2017). Projekty Infrastrukturalne w rejonie Trójmorza. Centrum Badań nad Bezpieczeństwem, Akademia Sztuki Wojennej. Retrieved from: http://www.cbb. akademia.mil.pl/g2/oryginal/2017_10/ospp-projekty-infrastrukturalne-w-regionie-trojmorza.pdf.

Polish Ministry of the Environment. (2003). Strategie redukcji emisji gazów cieplarnianych $w$ Polsce do roku 2020. Retrieved from: http://www.cieplej.pl/imgturysta/file/podglad/strategia\%20redukcji\%20 gazow_2020.pdf.

Polskie Radio. (2018, December 19). Polska uniezależnia się od rosyjskiego gazu. Podpisano kolejna umowe z USA. Retrieved from: http://seo.org.pl/nowelizacja-ustawy-o-oze-opublikowana-wdzienniku-ustaw/.

Prus, J. (2017, November 12). Białoruś: pierwszy reaktor elektrowni atomowej ruszy w grudniu 2019. Bankier.pl. Retrieved from: https://www.bankier.pl/wiadomosc/Bialorus-pierwszy-reaktor-elektrowniatomowej- ruszy-w-grudniu-2019-r-4020024.html.

Stowarzyszenie Energii Odnawialnej. (2018, July 2). Nowelizacja ustawy o OZE opublikowana w dzienniku ustaw. Retrieved from: http://seo.org.pl/nowelizacja-ustawy-o-oze-opublikowana-w-dziennikuustaw/.

Skłodowska, M. (2018, February 16). Szczyt klimatyczny w Katowicach - rozsądek czy ambicje?. WysokieNapiecie.pl. Retrieved from: https://wysokienapiecie.pl/8039-szczyt-klimatyczny-w-katowicachrozsadek-czy-ambicje/.

Śmigiel, S. (2017, October 3). Węgiel jednak $w$ odwrocie. Jakie sa energetyczne alternatywy dla Polski?. Forbes. Retrieved from: https://www.forbes.pl/gospodarka/odejscie-polski-od-wegla-aalternatywne-zrodla-energii/qb83qnz. 
Umbach, F. (2008). German Debates on Energy Security and Impacts on Germany's 2007 EU Presidency. In Energy Security. Visions from Asia and Europe. M. Antonio (Ed.). Basingstoke, New York: Palgrave Macmillan.

Wiśniewski, F. Odnawialne źródła energii. Energetyka Polska, Polish Ministry of Energy. Retrieved from: http://www.energetyka-polska.pl/default_037.html.

WysokieNapiecie.pl. (2016, June 28). Najwięksi emitenci CO2 w europejskim systemie handlowym. Retrieved from: https://www.facebook.com/wysokienapieciepl/photos/a.617122904981104.107374 $1826.617110411649020 / 1387997901226930 /$ ?type $=1 \&$ theater.

WysokieNapiecie. (2018, February 14). Najniższy udział wegla w polskiej energetyce od 100 lat. Retrieved from: https://wysokienapiecie.pl/8002-udzial_wegla_w_produkcji_energii_elektrycznej_w_polsce/.

Zaleski, P. (2015, August 25). Perspektywy rozwoju Odnawialnych Źródeł Energii w Polsce, Energetyka 24. Retrieved from: https://www.energetyka24.com/perspektywy-rozwoju-odnawialnych-zrodelenergii-w-polsce.

\section{Author}

\section{Zuzanna Samson}

samson.zuzanna@gmail.com - Leiden University, Faculty of Humanities 